\title{
Power applications for fuel-cell using switching regulators
}

\author{
V. Dega Rajaji ${ }^{1}$, Dr. K. Chandra Sekhar ${ }^{2}$ \\ ${ }^{1}$ Department of Electrical and Electronics Engineering, Acharya Nagarjuna University College of Engineering \& \\ Technology, Acharya Nagarjuna University, India \\ ${ }^{2}$ Department of Electrical \& Electronics Engineering, R.V.R \& J.C College of Engineering, India
}

\begin{tabular}{|c|c|}
\hline Article Info & ABSTRACT \\
\hline Article history: & Generally the switch mode power supply input voltage source is constant or \\
\hline Received Nov 08, 2018 & $\begin{array}{l}\text { shows insignificant little varieties.in any case, when fuel call used input } \\
\text { source the last assumption is not valid. A fuel cell stack is give a details of }\end{array}$ \\
\hline Revised Dec 17, 2018 & low and not controlled DC output voltage, moreover, when the demanded \\
\hline Accepted Feb 17, 2019 & $\begin{array}{l}\text { current increases the output voltage becomes low in a nonlinear form; from } \\
\text { now on, suitable controller is required to taken the previously mentioned }\end{array}$ \\
\hline Keywords: & $\begin{array}{l}\text { issues. In this article, a normal current-mode controller is planned to using a } \\
\text { joined model for an energy unit stack and a boost converter; besides, the }\end{array}$ \\
\hline Boost converter & resolving control method increasing the system stability and output voltage \\
\hline Current mode controller & regulation. The proposed energy system utilizes an energy component power \\
\hline Fuel cell & $900 \mathrm{~W}$. the proposed controller execution for output voltage regulation by \\
\hline Pi controller & $\begin{array}{l}\text { means of closed loop gain estimations and step load changes. What's more, a } \\
\text { correlation amongst open-and closed- loop estimations is made, where the } \\
\text { controller robustness is tried for vast load varieties and fuel cell stack output } \\
\text { voltage changes are shows on simulation results. }\end{array}$ \\
\hline
\end{tabular}

Copyright $\odot 2019$ Institute of Advanced Engineering and Science. All rights reserved.

\section{Corresponding Author:}

\author{
V. Dega Rajaji, \\ Department of Electrical and Electronics Engineering, \\ Acharya Nagarjuna University College of Engineering \& Technology, \\ Acharya Nagarjuna University, \\ Guntur, Andhra Pradesh State, India. \\ E-mail: rajajiyadav@gmail.com
}

\section{INTRODUCTION}

The reduction of gases emitted by the thermal vehicles is justifiable reason to motivate many researchers to analyze alternatives to traditional internal combustion engine $[1,2]$. Among these studies, the development of hybrid electric vehicles that use clean and renewable energy sources [3] as power modules. Power device is electrochemical vitality transformation gadget which straight forwardly deliver power, water and warmth by handling hydrogen and oxygen $[4,5]$.

Generally DC voltage generated by a fuel cell stack varies widely and is low in magnitude; it is between $20 \mathrm{~V}$ and $50 \mathrm{~V}$ at full-load, a DC-DC converter is responsible for absorbing power from the fuel cell, and therefore should be designed to match fuel cell ripple current specifications $[6,7]$ and should not conduct any negative current. A few DC-DC converters, for example, push-pull, and half bridge and full-bridge converters can be utilized to help the low voltage of the fuel cell to the required level $[8,9]$.

The mathematical models of these converters are very important for engineers to study the system dynamic behavior. However, the power converter models are normally time varying due to the switching action many papers are published in this field. Proposes an approach for fuel cell DC-DC converter controller using dynamic evolution control [10, 11].

Several approaches are applied to analyze the converters as the average models and small signals Dynamic performance of PWM dc-dc converter has been analyzed using state space averaging method and 
small signals $[8,12,13]$.Averaged Model of a high power Dual-Phase Boost DC-DC Converter for Fuel Cell Power Supply. In reference, the authors study the average circuit model of non-ideal basic converter operating in discontinuous conduction mode. Reference studied the control method of boost \& buck converter for the large capacitor fuel cell hybrid stationary power applications using small signal ac equivalent circuit model $[14,15]$ Based on the above issues, this paper proposes an average model for fuel cell DC-DC converter which can regulate the output voltage of the converters to avoid rapid load voltage variations $[16,17]$.

This plan depends on a double loop control that contains a proportional-integral (PI) voltage loop and a quick current loop utilizing a non-linear sliding controller. Also, the voltage loop is replace by an energy loop in light of a differential flatness control approach. Then again, a non-linear single-loop feedback control is proposed in $[18,19]$ to manage the task of a fuel cell based energy framework. This plan depends on the differential levelness idea also, which accomplishes the coveted reaction utilizing a basic algorithm. Approval of the proposed plan was accomplished by trial results, where steady state reaction, dynamic reaction and control heartiness were checked.

This paper intends to give a general knowledge over the mechanisms of control when the qualities of the input source (particularly a fuel cell stack) are utilized. Compactly, a PEM fuel cell stack is associated with a boost converter sustaining a resistive load $[20,21]$. The principle commitment depends on the plan of a robust controller to adapt legitimately extensive advance load changes in mix with the related stack output voltage varieties [22]. To this end, initial, a consolidate model is proposed to the general fuel cell stack/control converter framework [3, 23, 24] In view of this model, two control loop are implemented for voltage regulation.

\section{COMBINED FUEL-CELL STACK/BOOST CONVERTER MODEL}

A fuel cell is a hydrogen-based electrical energy source that creates low and unregulated DC voltage, where the output voltage diminishes in a non-liner model when the requested current increments. The stack output voltage terminals are associated with a DC/DC power converter to at long last give a voltage required to feed either a DC or an AC load. In the accompanying, a generally mathematical scientific depiction catching absolutely the coupling between the fuel cell stack and a DC/DC support converter is appeared in detail.

\subsection{Fuel-Cell Stack Static Properties}

A few articulations have been proposed in the open writing to foresee the synthetic and thermal dynamical conduct of PEM fuel cell. In any case, with the end goal of this work, an appropriate and simple to-deal with fuel cell stack articulation inducting electric properties perfect with power change is utilized. For example, an fuel cell stack static articulation for the output voltage which relies upon the output present and physical parameters is given in where $\mathrm{v} f$ is the fuel cell stack output voltage, if is the fuel cell stack current and $\mathrm{E} \mathrm{O}$ is the open-circuit voltage.

$$
v_{f}\left(i_{f}\right)=\frac{E_{o}}{1+\left(i_{f} / I_{h}\right)^{\delta}}
$$

The parameters $\delta$ and Ih rely upon the earth dampness conditions and stack temperature. These parameters together with EO are required to be figured for a given fuel cell stack. A Nexa module is utilized and portrayed in this work. Comment 1: The articulation that speaks to the static properties of the fuel cell stack (1) was taken from; however, a methodology is required to get (from accessible estimated information) the parameters $\delta$ and $\mathrm{Ih}$. In the accompanying, a clarification about the calculation of the parameters EO, $\delta$ and $\mathrm{Ih}$ is given. An arrangement of $\mathrm{N}$ discrete test tests $(\mathrm{ifexp}(\mathrm{k}), \operatorname{vfexp}(\mathrm{k}))$ with $\mathrm{k}=1,2,3, \ldots, \mathrm{N}$, comparing to the stack output current and voltage are required. For this situation, the examples are delineated in circles in Figure 1.

$$
\begin{aligned}
& \left(\frac{i_{f}}{I_{h}}\right)^{\delta}=\frac{E_{O}}{v_{f}}-1 \\
& \delta \log i_{f}-\delta \log I_{h}=\log \left(\frac{E_{O}}{v_{f}}-1\right)
\end{aligned}
$$

Expecting that (3) holds for every single recorded example (ifexp(k), vfexp(k)) with E known, at that point (3) has the frame. 


$$
a_{1} x+a_{0}=y
$$

Where,

$$
a_{1}=\delta ; x=\log i_{f} ; a_{0}=-\delta \log I_{h} ; y=\log \left(\frac{E_{O}}{v_{f}}-1\right)
$$

At last, utilizing the outstanding direct slightest square information fitting, the parameters $\delta$ and Ih can be gotten from the accompanying calculations (all sums are of the form $\sum \mathrm{kN}=1$ ):

$$
\begin{aligned}
& x_{k}=\log \left(i_{\text {fexp }}(k)\right) ; \\
& y_{k}=\log \left(\frac{E_{o}}{v_{f e x p}(k)}-1\right) ; \\
& a_{0}=\frac{\sum x_{k}^{2} \sum y_{k}-\sum x_{k} y_{k} \sum x_{k}}{N \sum x_{k}^{2}-\left(\sum x_{k}\right)^{2}} \\
& \text { Which yield to } \delta=\frac{N \sum x_{k} y_{k}-\sum x_{k} \sum y_{k}}{N \sum x_{k}^{2}-\left(\sum x_{k}\right)^{2}}=0.64, \\
& I_{h}=\log ^{-1}\left(-\frac{a_{0}}{\delta}\right)=82.86
\end{aligned}
$$

for $\mathrm{N}=22$ tests and $\mathrm{EO}=41.7 \mathrm{~V}$. A correlation between trial information and the articulation in (1) is given in Figure 1, which affirms the exactness of the depicted technique. Also, this static model (1) is constant for a substantial scope of current, including no current and greatest current.

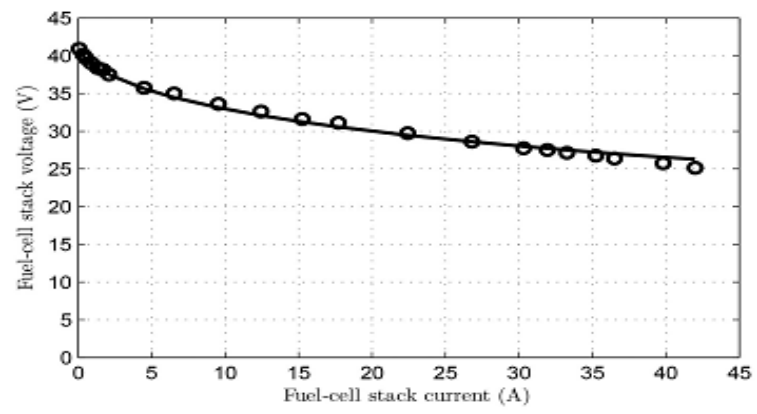

Figure 1. Fuel-cell stack/support converter framework (a) Nexa power module static output characteristics, information (circles), model (strong line), and reviewing some fundamental logarithm properties, (2) can be communicated as

\subsection{Overall Mathematical Representation}

The proposed physical execution of the fuel cell stack/boost converter system is appeared in Figure 2, where $\mathrm{Q}$ is the dynamic switch [metal-oxide-semiconductor field-effect transistor (MOSFET)], $\mathrm{u}$ the duty cycle, $\mathrm{D}$ the diode, $\mathrm{L}$ the filter inductor, $\mathrm{C}$ the filter capacitor and $\mathrm{R}$ theload resistance. Accordingly, if, iCf, iL, iC and I O are the normal fuel cell, coupling capacitor, inductor, capacitor and output streams, individually.

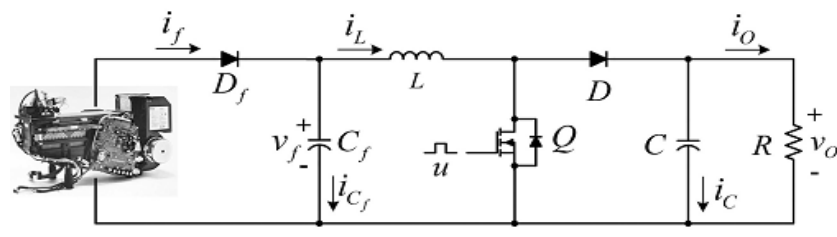

Figure 2. Fuel-cell stack/boost converter system (b) Fuel-cell stack/boost converter system 
The dynamic conduct of numerous classes of power circuits are dissected utilizing the idea of normal models, which can be controlled utilizing standard circuit procedures. Normal models can be inferred for high-frequency exchanging converters, where linearization can be effectively completed. In this sense, utilizing Kirchhoff laws when Q is ON/OFF and the current if from (2), the normal (ripple free) continuous non-linear model is obtained as:

$$
\begin{aligned}
& \dot{v}_{f}=\frac{1}{C_{f}}\left(I_{h}\left(\frac{E_{o}}{v_{f}}-1\right)^{\frac{1}{\delta}}-i_{L}\right) \\
& i_{L}=\frac{1}{L}\left(v_{f}-(1-u) v_{0}\right) \\
& \dot{v}_{o}=\frac{1}{C}\left((1-u) i_{L}-\frac{v_{0}}{R}\right)
\end{aligned}
$$

where the state vector is $[\mathrm{vf}, \mathrm{iL}, \mathrm{vO}] \mathrm{T} \in \mathbb{R}+3$ and the input $\mathrm{u} \in\left(\begin{array}{ll}0 & 1\end{array}\right)$. The non-linear differential conditions in (8) are said to be bilinear, since the information flag $\mathrm{u}$ is increasing the state factors vO and iL specifically.

Remark 2:

A link capacitor is associated in the middle of the fuel cell stack and the boost converter, then utilizes series inductor for a similar assignment. In steady state, the normal output voltage VO is more than the input Vf, likewise the inductor current IL equivalents to the fuel cell current I f; in this manner, the ostensible working states of (8) are observed to be:

$$
V_{0}=\frac{V_{f}}{1-U}, I_{L}=\frac{V_{0}}{R(1-U)}=I_{h}\left(\frac{E_{O}}{v_{f}}-1\right)^{1 / \delta}
$$

characterized, the subsequent fuel cell voltage $\mathrm{Vf}$ can be processed from the numerical arrangement of:

$$
V_{f}+\frac{V_{O}^{2 \delta}}{\left(R I_{h}\right)^{\delta}} V_{f}^{1-\delta}-E_{o}=0
$$

Note that ideal components and zero voltage misfortunes are expected in (8)-(10); accordingly, the numerical outcomes may vary from those by and by. Moreover, in steady state CCM task, the voltage and current riples for the lift converter because of the the switching action can be computed by:

$$
\Delta V_{0}=\frac{I_{o} U}{C f_{s}}, \Delta I_{o}=\frac{V_{f} U}{L f_{S}}
$$

furthermore, to guarantee CCM, the inductor esteem must be chosen as:

$$
L>\frac{U(1-U)^{2} R}{2 f_{S}}
$$

respects the linear normal small-signal demonstrate for the general framework as.

$$
\left[\begin{array}{c}
\dot{\tilde{v}}_{f} \\
\dot{\tilde{\imath}}_{L} \\
\dot{\tilde{v}}_{0}
\end{array}\right]=\left[\begin{array}{ccc}
-\frac{1}{C_{f} k} & -\frac{1}{C_{f}} & 0 \\
\frac{1}{L} & 0 & -\frac{1-U}{L} \\
0 & \frac{1-U}{C} & -\frac{1}{R C}
\end{array}\right]\left[\begin{array}{c}
\tilde{v}_{f} \\
\tilde{l}_{L} \\
\tilde{v}_{o}
\end{array}\right]+\left[\begin{array}{c}
0 \\
\frac{V_{0}}{L} \\
-\frac{I_{L}}{C}
\end{array}\right] \tilde{u}
$$

where the new state vector is $[\mathrm{v} \sim \mathrm{f}, \mathrm{i} \sim \mathrm{L}, \mathrm{v} \sim \mathrm{O}] \mathrm{T} \in \mathbb{R} 3$ and.

$$
k=\frac{E_{0} \delta I_{h}^{\delta} I_{f}^{\delta-1}}{\left(I_{h}^{\delta}+I_{f}^{\delta}\right)^{2}}
$$


The subsequent model (14) joins two subsystems elements and has just a single input $\mathrm{u} \sim \in \mathbb{R}$. This linear time-invariant model portrays around the conduct of the fuel cell stack/boost converter system for frequencies up to half of the exchanging recurrence $f \mathrm{~s}$. Moreover, it tends to be utilized for examination and controller outline of switching regulators.

\section{AVERAGE CURRENT-MODE CONTROLLER}

Normal CMC is a helpful method for facilitating the plan and enhancing the dynamic execution of switch-mode converters. Here, a philosophy to legitimately choose the controller gains for strength and execution reasons for existing is given. Moreover, detecting the inductor current can likewise be utilized for anticipating over-burden current through the converter. This control strategy utilizes a high-gain compensator, a low-pass filter and a PI controller to warrant: (I) that the average inductor current pursues the present reference, and (ii) output voltage direction.

The upside of this methodology is that any adjustment in the input voltage source has a quick impact in the controller (quick spread property). The general controller plan methodology is a twofold issue: (I) gain determination for the present loop, and (ii) gain choice for the voltage loop. With a specific end goal to infer the controller articulations, an arrangement for this method is proposed in Figure 3.

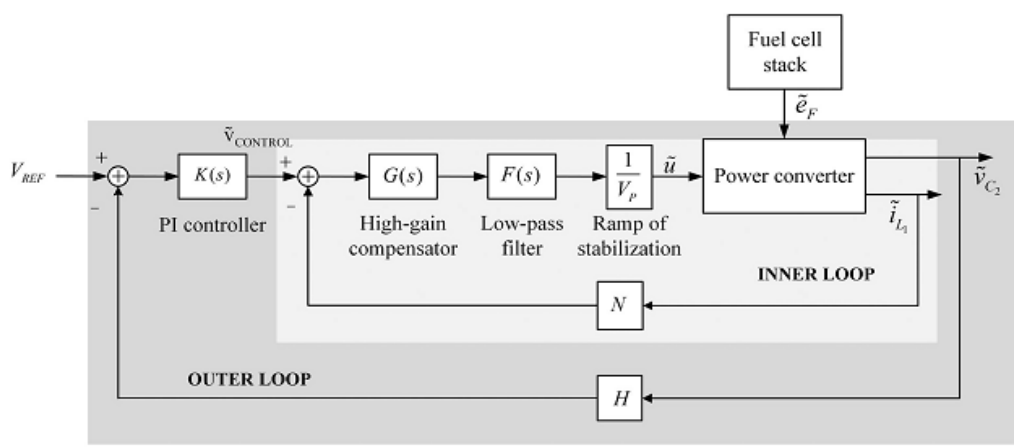

Figure 3. Average CMC scheme for a switching regulator

\section{Remark 3:}

The control plot proposed in has two control loop for output voltage direction too, however the high-gain compensator and the low-pass filters are coordinated to the voltage loop, in the meantime the present circle is actualized by a hysteresis controller. For robust stability of each loop, the accompanying prerequisites must be fulfilled:

- for relative stability, the slope at or close traverse frequency must be not more than $-20 \mathrm{~dB} / \mathrm{dec}$;

- to enhance consistent state precision, the gain at low frequencies ought to be high;

\subsection{Current Loop}

Note that both exchange capacities $\mathrm{F}(\mathrm{s})$ and $\mathrm{G}(\mathrm{s})$ can be actualized utilizing a single operational speaker as appeared in Figure 4.

$$
\tilde{u}=\underbrace{\frac{1}{V_{P}}\left(\frac{1}{1+\left(s / \omega_{P}\right)}\right)}_{F(s)} \underbrace{\left(G_{P} \frac{\left(\left(s / \omega_{z}\right)+1\right)}{s / \omega_{z}}\right)\left(I_{r e f}-N i_{L}\right)}_{G(s)}
$$

where $\omega \mathrm{P}$ remains for the area of the filter post, GP is the compensator gain, $\omega \mathrm{Z}$ is the area of the compensator zero and I ref is the out put of the voltage loop.

The zero $\omega \mathrm{Z}$ of the high-gain compensator ought to be set no less than half of the PWM exchanging frequency, $\mathrm{f} \mathrm{s} / 2$. For all intents and purposes, the zero is dictated by the relationship:

$$
\omega_{Z}=\frac{1}{R_{a} C_{a}}
$$

where $\mathrm{R}$ an and $\mathrm{Ca}$ are the resistence and capacitance relating to the current loop control circuit. 
The shaft $\omega \mathrm{P}$ of the low-pass filter, then again, ought to be set either at $\mathrm{f} s / 2$ or above. Utilizing the hardware in Figure 5, the shaft is dictated by:

$$
\omega_{P}=\frac{C_{a}+C_{b}}{R_{a} C_{a} C_{b}}
$$

where $\mathrm{C} \mathrm{b}$ is the capacitor associated to the current loop circuit as well.

The compensator gain is computed by:

$$
G_{P}=\frac{R_{a}}{R_{b}}
$$

where the resistance values must be carefully selected such that:

$$
G_{P}<\frac{5(1-U)^{2} R}{N V_{0}}
$$

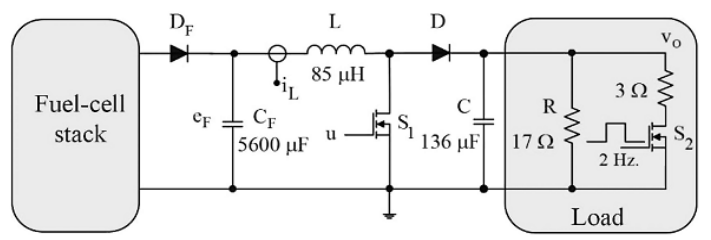

(a)

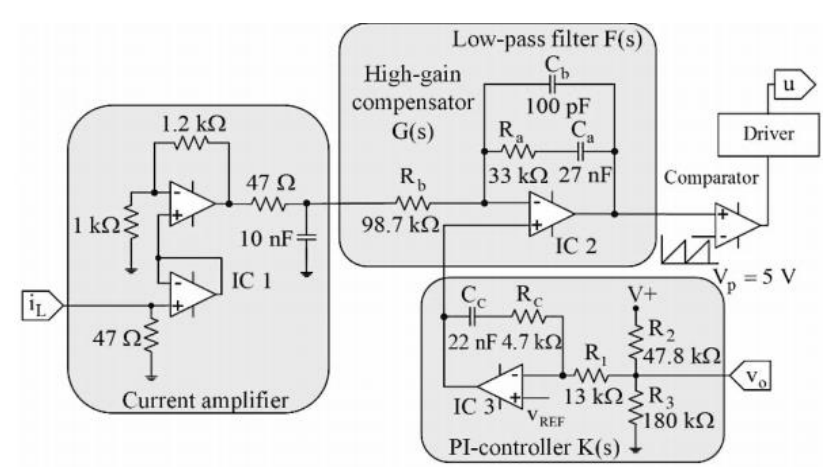

(b)

Figure 4. Switching controller (a) Combined fuel cell stack/boost converter, (b) Average current-mode controller

\subsection{Voltage loop}

The outer loop should be designed to provide a suitable steady state correction of the output voltage and can be implemented using a PI controller. The output of this loop is the current reference:

$$
I_{\text {ref }}=\underbrace{K_{C}\left(1+\left(1 / T_{i} s\right)\right)}_{K(s)}\left(V_{r e f}-H v_{o}\right)
$$

where $\mathrm{K} \mathrm{C}$ is the proportional gain, $\mathrm{Ti}$ is the integral time and Vref is the reference output voltage. In this case, the selection criteria should follow:

The proportional gain $\mathrm{KP}=\mathrm{RC} / \mathrm{R} 1$ is selected such that:

$$
K_{P}<\frac{10(1-U)}{H V_{0}}
$$

where the voltage divider is: 


$$
H=\frac{R_{1} \| R_{3}}{R_{1} \| R_{3}+R_{2}}
$$

Finally, the integral time is computed from:

$$
T_{i}=R_{C} C_{C}
$$

where $\mathrm{R} \mathrm{C}$ and $\mathrm{CC}$ are the resistance and capacitance values of the PI controller circuit, which must be selected such that $1 / \mathrm{Ti}$ is placed at least one decade below $\mathrm{f} \mathrm{s}$.

Remark 4:

Rather than VMC, here an internal loop is included. This enhances fundamentally the transient execution of the controller, since the transfer function $\mathrm{v} \sim \mathrm{O} / \mathrm{u} \sim$ of a boost converter has a correct half-plane zero, and a solitary voltage loop may not bargain legitimately with this issue.

\section{SIMULATION RESULTS}

\subsection{Open-Loop Test}

The reenactment open-loop time reaction of the framework is appeared in Figure 5a. It is perceptible that the test results are close enough to the hypothetical connection given in (9). Utilizing the MOSFET S 2 (trigger voltage $\mathrm{Vg}$ ), step changes of $2 \mathrm{~Hz}$ are connected to the output load which ranges from 2.56 to $17 \Omega$. The subsequent output voltage VO is appeared in Figure 5b, which changes for around $33 \mathrm{~V}$. Then again, Figure $5 \mathrm{c}$ demonstrates the progression changes on the fuel cell side.

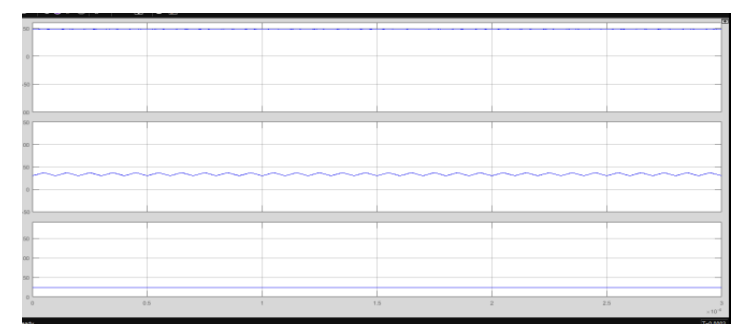

(a)

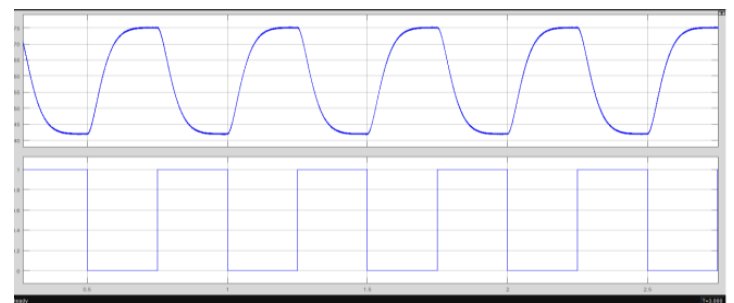

(b)

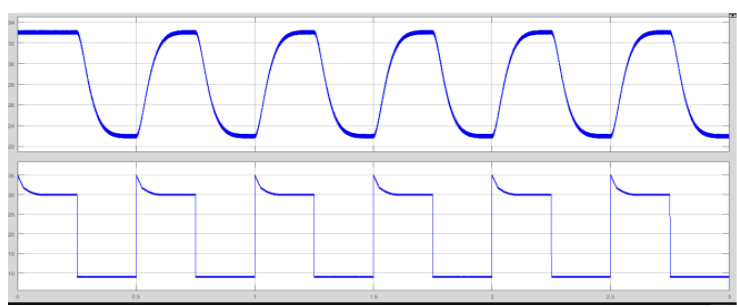

(c)

Figure 5. recreation results in open-loop reaction for step changes in load between 2.56 and $17 \Omega$ (a) (through and through) output voltage vO (20 V/div), inductor current iL (25 A/div) and fuel cell voltage vf $(20 \mathrm{~V} / \mathrm{div})$ (time: $10 \mu \mathrm{s} / \mathrm{div})$, (b) (start to finish) output voltage vO (20 V/div) and gate voltage Vg of MOSFET S2 (20 V/div) (time: $200 \mathrm{~ms} / \mathrm{div})$, (c) (start to finish) output voltage of the fuel cell stack vf (20 V/div) and output current of the fuel cell stack I f (10 A/div) (time: $200 \mathrm{~ms} / \mathrm{div})$ 


\subsection{Closed-loop test}

The switching regulator working condition comparing to $48 \mathrm{~V}$ yield voltage at ostensible load (no heap changes) is appeared in Figure 6(a). At this working condition, the fuel-cell stack is conveying a voltage of $24 \mathrm{~V}$. At the point when output changes are presented, the subsequent load voltage stays at $48 \mathrm{~V}$ as appeared in Figure 6(b), where it is clear the switching regulator is robust under expansive load varieties. The requested current range from 4 to $27 \mathrm{An}$, as is appeared in Figure 6(c). This is expected to the put away energy in the capacitor CF that repays the adjustments in the requested energy for closed-loop reaction. Note that the power device current in the open circle case Figure 6(c) presents a 5 An overshoot, in the mean time in the closed loop case Figure 6(c), the current does not present any overshoot; consequently, the existence cycle of the fuel cell is n't overpowered. The current ripple is appeared in Figure 6(d), which is little (1.2 A top to top) because of the capacitor $\mathrm{CF}$.

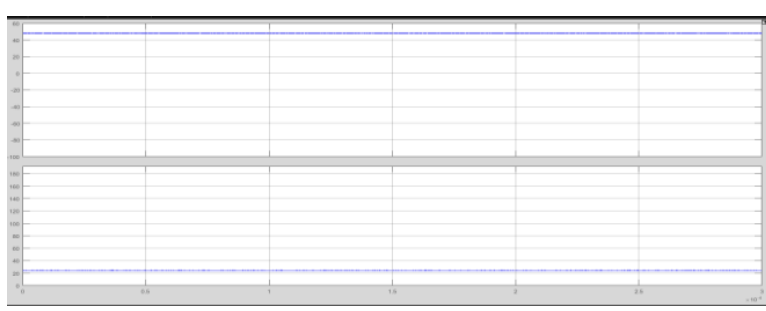

(a)

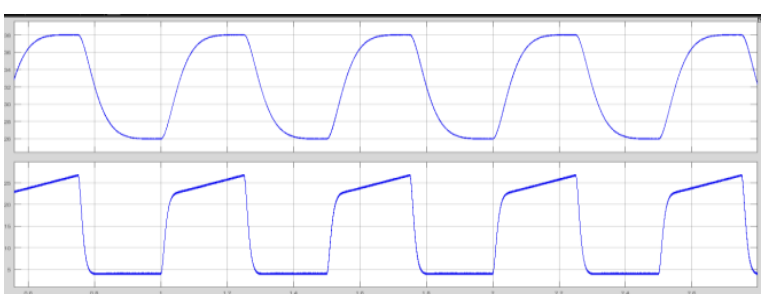

(c)

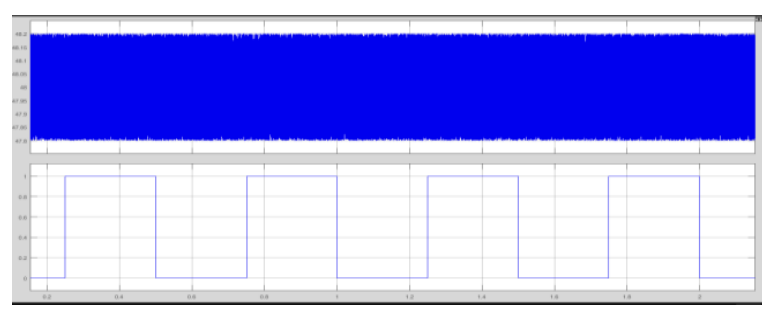

(b)

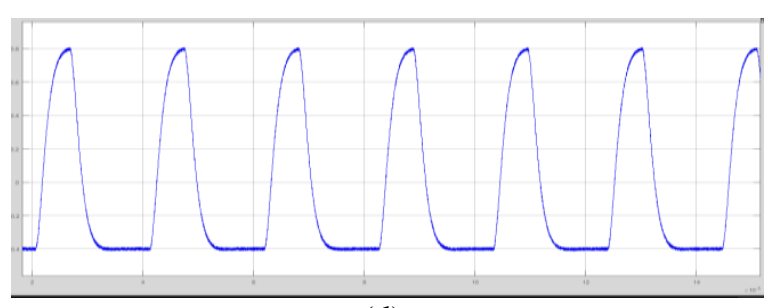

(d)

Figure 6. Closed-loop reaction (a) Response at ostensible load (2.56 $\Omega$ ). (Through and through) out put voltage vO (20 V/div) and fuel cell voltage vf (20 V/div) (time: $200 \mathrm{~ms} / \mathrm{div})$, (b) Response to step changes in the load somewhere in the range of 2.56 and $17 \Omega$ : (start to finish) output voltage $\mathrm{vO}(20 \mathrm{~V} / \mathrm{div})$ and gate voltage Vg of MOSFET S2 (20 V/div) (time: $200 \mathrm{~ms} / \mathrm{div}$ ), (c) Response to step changes in the heap somewhere in the range of 2.56 and $17 \Omega$ : (start to finish) feul cell voltage vf $(20 \mathrm{~V} / \mathrm{div})$, and output current of the fuel cell stack if (10 A/div) (time: $200 \mathrm{~ms} / \mathrm{div})$, (d) Output current ripple of the fuel cell stack I f (1 A/div) (time: $10 \mu \mathrm{s} / \mathrm{div})$

\section{CONCLUSIONS}

This paper deals with the output voltage control of a power module stack/boost converter system. The proposed control methodology is based everything considered CMC where two loop are executed, to be particular the interior loop where the inductor current is fed back using a high gain compensator and a lowpass filter, and the external loop where the output voltage is fed back by methods for a PI controller for steady state error regulation.. The assurance strategy for the controller parameters is unequivocally positive. The criteria given inside certification system stability and output voltage direction. The posts and zeros for the controller are set basically from the working exchanging recurrence of the converter. Furthermore, in view of the high-gain compensator of the internal loop, the converter execution is less sensitivity to parameter uncertainties and assortments of the fuel cell stack voltage. This control procedure was executed using minimal effort operational enhancers, reasonable for commercial applications. Finally, recreation results using a boost converter model show great robustness to huge variations on the load.

\section{REFERENCES}

[1] Tran, V.-L., Tran, N.-T., Yu, S.-H., et al.: 'Design a nonisolated fuel cell boost charger for lithium polymer batteries with a low output ripple', IEEE Trans. Energy Convers., 2015, 30, (2), pp. 605-614.

[2] Li, Q., Chen, W., Liu, Z., et al.: 'Active control strategy based on vector proportion integration controller for proton exchange membrane fuel cell grid-connected system', IET Renew. Power Gener. 2015, 9, (8),pp. 991-999. 
[3] Shadmand, M.B., Balog, R.S., Abu-Rub, H.: 'Model predictive control of PV sources in a smart de distribution system: maximum power point tracking and droop control', IEEE Trans. Energy Convers., 2014, 29, (4), pp. 913921.

[4] Vazquez-Oviedo, E.I., Ortiz-Lopez, M.G., Diaz-Saldierna, L.H., et al.: 'Modeling study of a combined fuel-cell stack/switch mode dc-dc converter',J. Fuel Cell Sci. Technol., 2014, 11, pp. 1-5.

[5] Carrasco, J.M., Garcia, L., Bialasiewiez, J.T., et al.: 'Power-electronic system for the grid integration of renewable energy sources', IEEE Trans. Ind. Electron., 2006, 53, (4), pp. 1002-1016.

[6] Thounthong, P., Davat, B., Rael, S., et al.: 'Fuel cell high-power applications', IEEE Ind. Electron. Mag., 2009, 3, pp. 32-46.

[7] Leel, J.-G., Choe, S.-Y., Ahn, J.-W., et al.: 'Modelling and simulation of a polymer electrolyte membrane fuel cell system with a PWM dc/dc converter for stationary applications', IET Power Electron., 2008, 1, (3), pp. 305-317.

[8] Rahmal, S.A., Varmal, R.K., Vanderheide, T.: 'Generalised model of a photovoltaic panel', IET Renew. Power Gener. 2014, 8, (3), pp. 217-229.

[9] Benson, Ch.L., Magee, Ch.L.: 'On improvement rates for renewable energy technologies: solar PV, wind, capacitors, and batteries', J. Renew. Energy, 2014, 68, pp. 745-751.

[10] Bahceci, S., Fedakar, S., Yalcinoz, T.: 'Examination of the grid-connected polymer electrolyte membrane fuel cell's electrical behaviour and control', IET Renew. Power Gener. 2016, 10, (3), pp. 388-398.

[11] El Fadil, H., Giri, F., Guerrero, J.-M., et al.: 'Modeling and nonlinear control of a fuel cell/supercapacitor hybrid energy storage system for electric vehicles', IEEE Trans. Veh. Technol.,2014, 63, (7), pp. 3011-3018 Hoogers, G.: 'Fuel cell technology handbook' (CRC Press, 2003).

[12] Naik, M.V., Samuel, P.: 'Analysis of ripple current, power losses and high efficiency of dc-dc converters for fuel cell power generating systems', Renew. Sustain. Energy Rev., 2016, 59, pp. 1080-1088.

[13] Guesmi, K., Essounbouli, N., Hamzaoui, A.: 'Systematic design approach of fuzzy PID stabilizer for dc-dc converters', Energy Convers. Manage., 2008, 49, pp. 2880-2889.

[14] Sira-Ramírez, H., Oliver-Salazar, M.-A., Leyva-Ramos, J.: 'Voltage regulation of a fuel cell-boost converter system: a proportional integral exact tracking error dynamics passive output feedback control approach'. American Control Conf. (ACC), Montreal, Canada, June 2012, pp. 2153-2158.

[15] Mohan, N., Undeland, T.-M., Robbins, W.-P.: 'Power electronics converters, applications, and design' (John Wiley \& Sons, 2003, 3rd edn.).

[16] Kabalo, M., Pairel, D., Blunier, B., et al.: 'Experimental evaluation of four phase floating interleaved boost converter design and control for fuel cell applications', IET Power Electron., 2013, 6, (2), pp. 215- 226.

[17] Thounthong, P., Pierfederici, S.: 'A new control law based on the differential flatness principle for multiphase interleaved DC-DC converter', IEEE Trans. Circuits Syst. II, Express Briefs, 2010, 57, (11), pp. 903-907.

[18] Thammasiriroj, W., Chunkag, V., Phattanasak, M., et al.: 'Nonlinear single- loop control of the parallel converters for a fuel cell power source used in $\{$ DC $\}$ grid applications', Int. J. Electr. Power Energy Syst., 2010, 65, pp. 4148.

[19] Thounthong, P., Davat, B.: 'Study of a multi-phase interleaved step-up converter for fuel cell applications', Energy Convers. Manage., 2010, 51, pp. 826-832.

[20] Hajizade, A., Golkar, M.A., Feliachi, A.: 'Voltage control and active power management of hybrid fuelcell/energy-storage power conversion system under unbalanced voltage sag conditions', IEEE Trans. Energy Convers., 2010, 25, (4), pp. 1195-1208.

[21] Shahin, A., Hinaje, M., Martin, J.-P., et al.: 'High voltage ratio dc-dc converter for fuel-cell applications', IEEE Trans. Ind. Electron., 2010, 57, (12), pp. 3944-3955.

[22] Gou, B., Na, W.-K., Diong, B.: 'Fuel cells, modeling, control and applications' (CRC Press, 2010).

[23] Leyva-Ramos, J., Lopez-Cruz, J.M., Ortiz-Lopez, M.G., et al.: 'Switching regulator using a high step-up voltage converter for fuel-cell modules', IET Power Electron., 2013, 6, (8), pp. 1626-1633.

[24] Shen, J.-M., Joul, H.-L., Wu, J.-C.: 'Transformerless three-port grid connected power converter for distribution power generation system with dual renewable energy sources', IET Power Electron., 2012, 5, (1), pp. 501-509. 